\title{
Comparing The South African Stock Market's Response To Two Periods Of Distinct Instability - The 1997-98 East Asian And Russian Crisis And The Recent Global Financial Crisis
}

Anmar Pretorius, North-West University, South Africa

Jesse de Beer, University of the Free State, South Africa

\begin{abstract}
This paper compares the South African stock market's response to two periods of distinct instability, namely the East Asian and Russian crisis of 1997-98 and the global financial crisis of 2007-09. Considering share prices, the Johannesburg Securities Exchange (JSE) was more severely affected by the earlier crisis, when the domestic fundamentals were weaker. The low levels of foreign reserves were the main cause of concern. The paper further empirically investigates volatility spillover between the JSE and various developed and emerging stock markets during the two crisis periods, employing twelve separate bi-variate GARCH models. The main contributors to volatility spillover during the East Asian and Russian crisis were Mexico, Thailand, Brazil, and Germany - predominantly emerging markets. During the second crisis period, Germany, US, Brazil, and UK played the dominant parts - predominantly developed markets. The importance of Germany in both periods can be attributed to the country's role as main export destination of South African goods in Europe.
\end{abstract}

Keywords: Global Financial Crisis; East Asian and Russian Crisis; JSE; Volatility Spillover

\section{INTRODUCTION}

iven the large costs associated with financial crises, an understanding of the elements that drive the propagation of crises is of vital importance. Both the East Asian and Russian crisis and the global financial crisis led to widespread contagion (Dungey et al., 2010) and both had a dramatic impact on South Africa. This is despite the fact that the South African economic fundamentals proceeding both crisis periods were very different from those factors that have been identified as the causes of the different crises. The rationale for focusing on the two crisis periods stems from the devastating impact of the crises on emerging markets, as well as very different global financial conditions at the onset of the two crisis periods.

The Johannesburg Securities Exchange (JSE) provides an interesting case study, since there were differences in the operating environment of the JSE during the two crisis periods. During the 1997-98 East Asian and Russian crisis, the JSE was a newcomer to the international stock market arena after years of sanctions and isolation, and liquidity on the JSE was low. During the recent global crisis the JSE was much more liquid and integrated with the world markets - partly due to institutional reforms of the JSE but also due to its established status as an important contributor to the FTSE advanced emerging markets index. The JSE is classified as an "advanced emerging market" and one of the best-regulated securities exchanges in the world (World Economic Forum, 2010). 
The aim of this paper is to compare the South African stock market's response to these two periods of distinct instability. The comparison includes: the response of the JSE, as well as an estimation of the cross-country spillover in volatility among the JSE and several advanced and emerging stock markets during the two crisis periods, employing multivariate GARCH (MGARCH) models.

Following Chudik and Fratzscher (2011), the paper takes a financial market perspective, analysing the response of equity markets as a proxy for the impact on the real economy. There are several reasons for this focus on the stock market. First is the availability of high frequency, recent data. Financial crises comprise a relatively short period, making it inherently difficult to model volatility spillovers and/or crisis transmission with macroeconomic data that is available only at quarterly or monthly frequency. Secondly, stock market prices are intrinsically forward-looking and as such reflect expectations for future earnings, as well as the risk-adjusted rate at which these future earnings are discounted. Thus, stock market prices are indicative of both changes in macroeconomic fundamentals and investors' risk appetite. Thirdly, stock markets were the first to feel the impact of the crises. Stock market prices are among the more successful early-warning indicators of crises in emerging markets. This was confirmed by Kaminsky, Lizondo, and Reinhart (1998) for the East Asia crisis of the late 1990s, and Rose and Spiegel (2009) for the global financial crisis in 2008. The rationale for studying volatility spillovers from international stock markets stems from the important role that foreign investors play on the JSE, especially during times of financial turmoil.

This paper contributes to the literature on three fronts. First, it contributes to the literature on the propagation of financial crises, with specific emphasis on the stock market impact of the crisis on emerging markets. Secondly, it relates to the broad literature on the drivers of equity prices and the role of domestic and global factors in this regard. Thirdly, it complements and extends the results of existing empirical studies by including a broad set of emerging and developed stock markets and by providing an in-depth country case study of the propagation and consequences of two distinct periods of financial crisis. The explicit comparison between these two periods provides valuable insights into how changes in domestic policy variables, the international financial architecture and policies related specifically to the stock market can change the nature of spillovers through time.

\section{RELATED LITERATURE: STOCK MARKETS AND FINANCIAL CRISES}

This study is related to two broad strands of the literature: the drivers of equity prices, on the one hand, and the voluminous literature on the propagation of financial crises in general, on the other hand. This section focuses on some of the literature that provides an explanation for the origin, transmission, and impact of the two crisis periods that fit the South African experience.

\subsection{Drivers of Equity Prices}

The extensive literature on the general drivers of equity prices includes the Gordon (1962) model and the APT (Chen, Roll, \& Ross, 1986), which provides frameworks to study the behaviour of macroeconomic variables on stock prices. Although empirical studies on the topic have been quite diverse, the approaches focus primarily on two sets of factors as determinants of equity prices: domestic/fundamental and global/financial (IMF, 1998, 2000). Several studies point to the strong influence of external factors, such as global financial conditions on emerging market equity prices (for example IMF, 2008; IMF, 2000; Shiller, 2000).

In the South African context, the results from the research of Coetzee (2002), Moolman and Du Toit (2005), and Durodola (2006) indicate a relationship between JSE stock prices and, in particular, monetary variables, exchange rates and foreign stock indices, with limited impact of such variables as industrial production. Chinzara (2011) shows that macroeconomic uncertainty significantly influences stock market volatility on the JSE and, more specifically, that financial crises increase volatility in the stock market and in most macroeconomic variables. He also found that volatility in short-term interest rates and exchange rates has the largest impact on stock market volatility.

More closely related to our own study is the literature on the importance of the volatility of foreign stock markets in explaining domestic South African stock market volatility. This is documented in Samouilhan (2006) and 
Chinzara and Aziakpono (2009). Chinzara and Aziakpono (2009) found that volatility in major developed and emerging stock markets explain volatility in the South African stock market. However, own past volatility explains a higher proportion of the variation in JSE current volatility than aggregate volatility in the foreign stock markets.

\subsection{Propagation of Financial Crises}

Earlier crisis literature focused on the distinction between fundamental causes of crises (when the economy is in a state of distress) and crises of the self-fulfilling variety that occur even in countries with immaculate market fundamentals. The fundamentals approach can be found in Kaminsky (1999) and Krugman (1979), while examples of the self-fulfilling variety are present in Eichengreen and Wyplosz (1993) and Obstfeld (1996). This distinction is also found in the literature on channels of crisis transmission. Our study focuses on the stock market channel, but in order to provide perspective, we place this channel in the context of crisis transmission channels in general. This literature distinguishes between two broad groups transmission channels: fundamental causes and crisis transmission through investor behaviour (Hernándes \& Valdés, 2001, p. 4; Kumar \& Persaud, 2001, p. 8; Rose \& Spiegel, 2009). Other authors distinguish between real and financial linkages. A related distinction is between pure contagion, which cannot be explained by changes in fundamentals, and spillovers based on fundamental factors (Fratzscher, 2000, p. 4; Van Rijckeghem \& Weder, 2001), where real linkages focus on the trade channel and a common shock. Financial linkages, on the other hand, include direct financial linkages and indirect financial linkages via investor behaviour.

The explanation of crisis transmission via financial linkages has become more prominent in the aftermath of the East Asian crisis, partly due to the enormous increase in the size and interlinkages of global financial markets (Kaminsky \& Reinhart, 1998; De Gregorio, Edwards, \& Valdes, 2000). There is some overlap between theories classified as fundamental causes and investors' behaviour, and it has proven difficult to empirically disentangle transmission mechanisms according to the above classifications (Claessens \& Forbes, 2004). For example, countries that are closely linked in trade also tend to have strong financial linkages (see Kaminsky \& Reinhart, 2001). Some studies even find that some of the contagion previously identified as attributable to trade linkages may actually stem from financial linkages (see for example Fratzscher, 2000).

\subsubsection{Real Linkages}

Notwithstanding these difficulties in disentangling crisis transmission mechanisms, several such channels are well documented. Real linkages are usually associated with the trade channel and a common or global shock (which has also been called a "monsoonal effect"). The latter can refer to a major economic shift in industrial countries (such as changes in interest rates or currency values), a change in commodity prices, and/or a reduction in global growth (Masson, 1998). In this context, it can be argued that the drop in commodity prices in 1998 contributed to the crisis in Chile, South Africa, and Australia.

The trade channel is a second "real" channel of crisis transmission and includes an income effect and a price effect (or competitive devaluation). The price effect is transmitted through the expected loss of competitiveness arising from exchange rate depreciation in export competitor countries, while the income effect stems from expected output contractions of major trading partners due to the crisis (Caramazza et al., 2000, p. 44; Claessens, Kose, \& Terrones, 2009). Earlier studies focusing on the East Asian crisis stress the importance of the foreign trade channel (see Eichengreen, Rose, \& Wyplosz, 1996; Glick \& Rose, 1999; Eichengreen \& Rose, 1998).

\subsubsection{Financial Linkages}

Financial linkages can in turn, be classified into two broad categories: direct financial linkages and investor behaviour. Direct financial linkages featured prominently in the context of the first part of the 2007-09 crisis and especially the experience of developed markets in the United States of America (US) and Europe. This focus is on exposure to sub-prime-related assets, the prevalence of exotic financial instruments and the potential contagious role of the international interbank market (see for example Bruinshoofd et al., 2010; Gros \& Micossi, 2008; Davis, 2008).

Another example of financial linkages refers to the "common creditor channel" focusing on mutual dependence on foreign creditors. This explanation featured prominently in the literature on the East Asian crisis 
(Kaminsky \& Reinhart, 2000; Caramazza, et al., 2000; Van Rijckeghem \& Weder, 2001). The "common creditor" channel is likely to be irrelevant in the 2008 crisis with the downturn centered on the world's largest debtor (Rose \& Spiegel, 2009).

Different classifications and descriptions of the role of investor behaviour in the international transmission of financial crises are found in the literature (for example, see Claessens \& Forbes, 2004; Hernándes \& Valdés, 2001). The following broad categories are discussed: liquidity problems, informational asymmetries and investor reassessment (or the so-called wake-up call), and a general change in risk aversion/investor sentiment. The underlying theme of most of these theories is that although investor behaviour is often ex-ante individually rational, collectively it can lead to excessive co-movements in market prices that cannot be explained by real fundamentals.

Calvo and Mendoza (1998) and Kodres and Pritsker (2002) and others have empirically explored the channel of informational asymmetries. The basic implication of models of this sort is that each individual market agent may rationally respond more to the actions of other agents than to his/her own private information. Incentive structures and financial market practices can also contribute to herd behaviour. Froot, O'Connell, and Seasholes (2001) and Kaminsky, Lyons, and Schmukler (2001) emphasise the behaviour of emerging market funds in this regard.

Liquidity-related crisis transmission occurs when losses in one market force economic agents either to liquidate leveraged positions or to rebalance their portfolios in response. Empirical studies that confirmed the relevance of this channel during the East Asian and Russian crisis includes Kaminsky, Lyons, and Schmukler (2001), Calvo and Mendoza (1998), and Kodres and Pritsker (2002), while Brunnermeier and Pedersen (2009) explore this channel in the context of the 2007/2008 crisis. Ehrmann, Fratzscher, and Mehl (2009) relate the "liquidity squeeze" resulting in a flight to liquidity" to a "retrenchment" or "repatriation" hypothesis.

Exogenous shifts in investors' risk appetite constitute a related crisis transmission channel. In terms of the East Asian crisis, the co-movement of perceived risky assets such as Brazilian bonds, the Thai baht, the South African rand, and US junk bonds, even though Brazil, Thailand, South Africa, and the US share few macroeconomic trends, was indicative of this channel (Kumar \& Persaud, 2001, p. 6). A global increase in risk aversion is also often cited as the major channel of international financial crisis transmission during the 2007/2008 crisis. A "global deleveraging" process was evident in the substantial shift across asset classes out of equities and into (particularly US) government bonds during the height of the crisis. The nature of these two channels suggests that countries that are highly integrated into the international financial system may be particularly prone to contagion, independent of their underlying level of risk.

A related argument is that a crisis in one country may constitute a "wake-up call" for investors to reassess fundamentals in other countries, thus possibly spreading the crisis across economies (Fratzscher, 2000; Goldstein, 1998; Basu, 1998). In other words, the crisis in one country may alert investors to potential dangers in other countries with similar vulnerabilities. Van Rijckeghem and Weder (2001) found evidence that supports the "wakeup call" hypothesis in the context of the Russian crisis, while the empirical results of Didier, Love, and Peria (2010) suggest evidence of a wake-up call during the first part of the global financial crisis.

\subsubsection{Previous Empirical Results}

In the South African context, only a few published papers directly examined the impact of the East Asian and Russian crisis on the South African financial markets. Boshoff (2006) used firm-level stock return data to evaluate how financial crises were transmitted to South African financial markets during the East Asian, Russian, and Argentinean crises. He concluded that trade and financial linkages do not explain the impact of international crises on larger South African firms and therefore that international crises have been transmitted to this country as a result of investor herding behaviour, rather than weak South African macroeconomic fundamentals. Forbes and Rigobon (2002) showed that during the 1997 Asian crisis, no emerging market, South Africa included, suffered contagion. The results of the research of Collins and Biekpe (2003) contradict the Forbes and Rigobon results. They found that, along with Egypt, South Africa is one of the most integrated countries in Africa with regard to its financial markets. Based on their degree of integration, Egypt and South Africa were the most affected by contagion 
during the crisis. This study extends the empirical data by focusing on an in-depth country experience for South Africa.

Several empirical studies investigated the transmission of the global financial crisis to emerging market countries through the stock market channel. None of these studies focus specifically on South Africa, although some studies based on firm-level data include South African firms. In general, these studies point to a difference in the transmission of the crisis during the two parts of the crisis. During the first part, investors seemed to differentiate between markets with different fundamentals, evident of the "wake-up" hypothesis. During the second part of the crisis, contagion seemed to dominate, and funds were withdrawn from liquid markets worldwide, irrespective of country-specific fundamentals. Didier, Love, and Peria (2010) found evidence of a wake-up in the first stage of the crisis, but not after the collapse of Lehman. This suggests that investors cared about fundamentals in the early stages of the crisis. In the second period, the strongest significance is obtained for stock market turnover, which suggests that in the worst period of the crisis investors withdrew from liquid markets. In particular, markets with high ratios of equity holdings by US investors, high levels of portfolio inflows, greater liquidity, and more developed stock markets were correlated more closely with the US market. Their findings further indicate that the main channel of transmission appears to have been financial, and they find no support for a real/trade channel of transmission.

Using firm-level data, Ehrmann, Fratzscher, and Mehl (2009) find that equity portfolios with a high degree of integration with the US market before the crisis were more affected than segregated ones, which suggests that macro country risk dwarfed micro, firm-level risk as a global transmission channel. Investors discriminated more across countries (and governments) rather than across firms during the crisis. Their results also suggest that financial integration with US markets and country risk played central roles in making the crisis global, and thereby give support to the hypotheses of retrenchment and repatriation of capital to US markets as well as to that of global deleveraging and risk exposure reduction as key factors explaining why the crisis spread globally.

In contrast, Bekaert et al. (2011), using global firm-level stock price data, find evidence of a "wake-up call hypothesis" and that countries with poor domestic fundamentals experienced by far the largest equity market declines and contagion. They found statistically significant, although economically insignificant, evidence of systematic contagion from US markets, but strong evidence of domestic contagion: the co-movement of portfolios within a country increased systematically during the crisis.

The differentiated impact of the US stock market on commodity-producing and non-commodity-producing countries is documented by Aloui, Aïssa, and Nguyen (2011). Their results show strong evidence of time-varying dependence between each of the BRIC markets and the US markets, but the dependency is stronger for commodityprice-dependent markets (Brazil and Russia) than for finished-product, export-oriented markets (India and China). Thus, their results suggest that heterogeneous economic structures and especially different trade profiles could be a relevant explanatory factor of the cross-market interdependences.

Moosa (2010) examined stock market contagion from the US to the markets of the Gulf countries (Bahrain, Kuwait, Oman, Qatar, Saudi Arabia, and the United Arab Emirates) during 2007-08. The empirical results show that the collapse of these stock markets did not result purely from contagion from the US stock market and oil prices decline. Local factors, including increasing debt levels, overheated real estate markets, and drying up of liquidity were more influential in triggering the collapse.

This study complements and extends the results of these studies by including a broader set of emerging stock markets and by focusing specifically on two crisis periods. We also provide an explicit comparison between these two periods, shedding light on how changes in domestic policy variables, the international financial architecture, and policies related specifically to the stock market can change the nature of spillovers over time.

\section{BACKGROUND: THE MANIFESTATION OF THE TWO CRISES}

Before focusing on the impact of the two crises on the JSE, it is necessary to compare and contrast the nature of the two crises in terms of their origins and similarities. Over-leveraging and bad debt were important common factors in fomenting both the crises. Weak banking systems, with inadequate supervisory oversight and 
under-capitalised banks, were recognised by the Bank of International Settlements (BIS) as key issues for the countries affected by the 1997-98 crisis. Unsustainable exchange rate arrangements, unsustainable budget deficits, asset price bubbles, and increasing credit growth also played major roles. The recent global financial crisis could be attributed to the solvency of the global banking system, widespread increases in asset prices and unusually low real interest rates (BIS, 2009).

\subsection{The East Asian and Russian Crisis of 1997-1998}

The start of East Asian part of the 1997-1998 crisis is generally considered to date to July 1997, when the pegging of the Thai baht to the US dollar was abandoned. This led to capital withdrawals and speculative attacks on Asian currencies, causing the exchange rate and financial asset prices in Thailand to decline sharply. Spillover effects were soon felt in other Asian countries, notably Indonesia, Korea, Malaysia, and the Philippines. Economic fragility in the East Asian countries and political uncertainty that provoked instability in financial markets were at the heart of the crisis (Kaminsky \& Schmukler, 1999). The turmoil in Asian financial markets and the recession in Japan contributed to a slowdown in global economic growth in the second half of 1997 and in 1998.

The second part of the crisis erupted in August 1998, when the Russian government announced a depreciation of the rouble and a unilateral restructuring of external debt (Kaminsky \& Reinhart, 2002). The surprise announcement on 2 September 1998 of the bankruptcy of Long Term Capital Management (LTCM) compounded the international financial turmoil in a significant manner. This second part of the crisis led to widespread contagion and had a pronounced impact on stock markets worldwide, especially emerging markets, including South Africa. A general "flight to quality" meant that capital flows were redirected to the advanced economies. Following the announcement, the shares of German banks were exposed to economies around the world. Combined with falling commodity prices and consequent significant declines in the export earnings of commodity-producing countries, this aggravated the external financing difficulties of emerging-market economies.

The crisis had a pronounced impact on several financial variables. The JSE all-share index fell by more than $36 \%$ in US\$ terms during the worst part of the crisis (see Table 1 for more details). The major impact on the JSE became visible during the period May - September 1998. This was accompanied by record high interest rates and a depreciating currency. Heavy selling of South African fixed-interest securities by non-residents resulted in record high yields on long-term government bonds and bond spreads rose dramatically (South African Reserve Bank, 1998). In contrast to the dramatic impact on the financial sector, the impact on the real South African economy was muted. Declines in exports and production were relatively mild and short-lived (South African Reserve Bank, 1998). However the dramatic impact on interest rates did have an adverse impact on bank lending.

\subsection{The 2007-09 Crisis}

The first part of the crisis, the sub-prime crisis, occurred during the third quarter of 2007 when losses in the US sub-prime mortgage market unsettled global financial markets. The bankruptcy of Lehman Brothers, announced on 15 September 2008, marked the start of the global spread of the financial crisis (Frankel \& Saravelos, 2010). It is generally acknowledged that the global financial crisis was transmitted via international financial linkages, with the original shock in the US financial system leading to disruption in the financial systems of several advanced European countries. Exchange controls probably protected South Africa from the worst impact of the crisis as many toxic type instruments could not be traded or held. ${ }^{1}$

In terms of the transmission to emerging stock markets, the IMF (2010) describes three phases of transmission of the crisis. First, some emerging markets, including South Africa, seemed to decouple from advanced economies between the start of the sub-prime crisis in August 2007 and the collapse of Lehman. Lehman's collapse triggered panic in the global financial system, and stock markets around the world fell almost uniformly. On the JSE, the most dramatic fall occurred in October 2008, in line with international experience. The crisis also rapidly spilled over into the real economy of virtually all countries, with dramatic speed and apparent synchronicity.

\footnotetext{
${ }^{1}$ The authors would like to thank an anonymous reviewer for this comment. 
The impact on the South African real economy is evident from large declines in export values, GDP growth, and employment numbers during the worst part of the crisis, starting in the last quarter of 2008 (South African Reserve Bank, 2008). For example, GDP declined by $6.4 \%$ in the first quarter of 2009. Mining and manufacturing production and exports were hit particularly hard, with manufacturing losing $22.1 \%$ and $10.9 \%$ in the first and the second quarter of 2009, respectively. Declines in export values varied between 19\% and 35\% (compared to the same month in the previous year) every month from November 2008 to April 2009.

\subsection{The Impact of the Two Crisis Periods on Various Stock Markets}

The following two tables provide an indication of the impact of the two crisis periods on selected emerging and developed country stock markets.

Table 1: Impact of the East Asian and Russian Crisis on Selected Stock Markets - Returns Calculated in US\$ and Local Currency

\begin{tabular}{|c|c|c|c|c|}
\hline & \multicolumn{2}{|c|}{$\begin{array}{c}\text { East Asian and Russian } \\
\text { May } 1998 \text { - Oct } 1998\end{array}$} & \multicolumn{2}{|c|}{$\begin{array}{c}\text { East Asian and Russian } \\
\text { July } 1997 \text { - Oct } 1998\end{array}$} \\
\hline & US \$ & Local Currency & US \$ & Local Currency \\
\hline \multicolumn{5}{|c|}{ Emerging Markets } \\
\hline Brazil & -42.24 & -39.74 & -53.12 & -48.05 \\
\hline China & -32.78 & -32.79 & -60.48 & -60.47 \\
\hline Hungary & -29.35 & -26.90 & -3.56 & 11.86 \\
\hline India & -32.99 & -28.54 & -42.32 & -31.76 \\
\hline Mexico & -29.97 & -16.97 & -16.19 & -2.12 \\
\hline Poland & -30.02 & -11.12 & -23.24 & 17.46 \\
\hline Russia & -81.72 & -81.72 & -85.31 & -85.31 \\
\hline South Africa & -36.37 & -29.32 & -37.63 & -22.74 \\
\hline Thailand & -15.66 & -16.97 & -39.10 & -28.88 \\
\hline \multicolumn{5}{|c|}{ Developed Markets } \\
\hline Australia & -8.62 & -4.17 & -18.06 & -0.83 \\
\hline Germany & -2.29 & -9.05 & 25.33 & 19.29 \\
\hline UK & -9.55 & -10.02 & 16.04 & 14.90 \\
\hline USA & -1.27 & & 24.36 & \\
\hline
\end{tabular}

Source: Calculated from MSCI index values. Returns calculated as percentage change in index value at beginning of period compared to end of period.

Even though markets that were most severely impacted by the East Asian crisis are not included in the sample, the devastating impact of this crisis on emerging stock markets is clear. Furthermore, most of these countries also experienced dramatic currency depreciation, with resulting large stock market losses, especially when measured in US\$. During the first part of the East Asian crisis, the JSE suffered much lower losses than the majority of emerging markets in the sample. However, during the second part of the crisis, the JSE suffered large losses and the depreciation of the rand compounded these losses in dollar terms. These losses were still lower than those of most of the other emerging markets. Although the developed markets suffered losses during the height of the second part (Russian/LTCM) part of the crisis, these losses were recovered quickly.

Table 2: Impact of the Global Financial Crisis on Selected Stock Markets - Returns in US\$ and Local Currency Selected Periods During the Global Financial Crisis

\begin{tabular}{|c|c|c|c|c|c|c|}
\hline & \multicolumn{2}{|c|}{$9 / 3 / 2007-9 / 1 / 2008$} & \multicolumn{2}{|c|}{$9 / 1 / 2008-12 / 31 / 2008$} & \multicolumn{2}{|c|}{$9 / 15 / 2008-3 / 13 / 2009$} \\
\hline & US\$ & Local Currency & US\$ & Local Currency & US\$ & Local Currency \\
\hline \multicolumn{7}{|c|}{ Emerging Markets } \\
\hline Brazil & -17.30 & 11.16 & -51.56 & -31.36 & -35.74 & -17.55 \\
\hline China & -23.15 & -23.04 & -28.31 & -28.82 & -22.55 & -22.96 \\
\hline Hungary & -14.32 & -25.32 & -54.48 & -46.66 & -68.59 & -56.99 \\
\hline India & -13.25 & -6.25 & -42.51 & -36.61 & -43.45 & -36.78 \\
\hline Mexico & -13.04 & -18.36 & -38.17 & -17.22 & -42.25 & -21.33 \\
\hline Poland & -19.27 & -12.23 & -46.41 & -27.08 & -58.84 & -34.45 \\
\hline Russia & -10.92 & -11.38 & -63.18 & -61.06 & -49.63 & -52.61 \\
\hline
\end{tabular}


Table 2 cont.

\begin{tabular}{|l|c|c|c|c|c|c|}
\hline South Africa & -12.91 & -6.31 & -26.86 & -12.66 & -30.81 & -14.50 \\
\hline Thailand & -21.18 & -24.54 & -36.09 & -33.63 & -27.04 & -21.49 \\
\hline Developed Markets & -15.15 & -18.07 & -39.23 & -26.01 & -41.97 & -28.54 \\
\hline Australia & -12.82 & -18.66 & -31.70 & -28.31 & -43.56 & -37.88 \\
\hline Germany & -21.59 & -12.03 & -36.85 & -20.99 & -44.05 & -28.18 \\
\hline UK & -12.34 & -30.03 & & -36.37 & \\
\hline USA &
\end{tabular}

Source: Calculated from MSCI index values

The calculated returns in Table 2 point towards the decoupling of emerging markets during the first part of the crisis (2007-08) and recoupling during the second part of the crisis (2008-09). One possible reason, and one that can also be linked to the wake-up hypothesis, is the sharp decline in commodity prices during the second half of 2008. Some commentators refer to this as a commodity bubble that peaked in mid-2008 and then subsequently collapsed (Caballero, Farhi, \& Gourinchas, 2008).

During both parts of the crisis, the JSE was less affected than most of the other emerging market countries in the sample, most notably the BRIC countries (Brazil, Russia, India, China). Especially during the second (and worst) part of the crisis, JSE returns were towards the higher end of the spectrum (lower negative returns than most countries in the sample). In US\$ terms, the US stock market was the only market in the sample that performed better than the JSE during this period. The general flight to quality during this sub-period is reflected in the relative overperformance of developed markets.

\subsection{Comparing South African Economic Indicators during the Crisis Periods}

Taking into account the variables indicating the vulnerability of a country, Table 3 compares some of these indicators across the two crisis periods. Indicators of crisis vulnerability were stronger during the global financial crisis - particularly the foreign reserve position. At the onset of the East Asian crisis South Africa had just enough reserves to pay for 3.8 weeks' of imports. This, together with the South African Reserve Bank's policy of a managed floating exchange rate, left the local currency extremely vulnerable to speculative attacks.

Table 3: Fundamental South African Economic Indicators during the Two Crisis Periods

\begin{tabular}{|c|c|c|c|c|c|c|}
\hline & $\begin{array}{c}\text { Budget } \\
\text { Deficit as \% } \\
\text { of GDP }\end{array}$ & $\begin{array}{l}\text { Total Foreign } \\
\text { Debt as \% of } \\
\text { GDP }\end{array}$ & $\begin{array}{c}\text { Current } \\
\text { Account as \% } \\
\text { of GDP }\end{array}$ & $\begin{array}{c}\text { Net Direct } \\
\text { Investment } \\
\text { (Rmillion) }\end{array}$ & $\begin{array}{c}\text { Net Portfolio } \\
\text { Investment } \\
\text { (Rmillion) }\end{array}$ & $\begin{array}{c}\text { Imports } \\
\text { Covered by } \\
\text { Reserves } \\
\text { (weeks) }\end{array}$ \\
\hline 1997Q1 & -6.2 & 26.4 & -1.7 & 813 & 7317 & 3.8 \\
\hline 1997Q2 & -7.6 & 26.4 & -1.3 & 5104 & 11564 & 6.1 \\
\hline 1997Q3 & -3.4 & 26.4 & -1.2 & -1325 & 13367 & 7.1 \\
\hline 1997Q4 & -1.1 & 26.4 & -1.7 & 2164 & -1668 & 7.3 \\
\hline 1998Q1 & -1.8 & 28.3 & -0.5 & -553 & 19359 & 8.2 \\
\hline 1998Q2 & -7.6 & 28.3 & -1.0 & 1079 & 11211 & 8.8 \\
\hline 1998Q3 & -2.9 & 28.3 & -2.7 & -6350 & -6529 & 7.4 \\
\hline 1998Q4 & 1.1 & 28.3 & -2.8 & -913 & -3666 & 7.4 \\
\hline 200701 & 10 & 263 & 68 & 1605 & 24343 & 130 \\
\hline 2007Q2 & -1.1 & 26.3 & -6.2 & -1757 & 35647 & 13.1 \\
\hline 2007Q3 & 0.0 & 26.3 & -8.4 & 11885 & 19866 & 13.2 \\
\hline 2007Q4 & 2.8 & 26.3 & -7.2 & 7401 & -6397 & 13.0 \\
\hline 2008Q1 & 1.6 & 26.2 & -8.5 & 39744 & -22173 & 14.7 \\
\hline 2008Q2 & -0.4 & 26.2 & -7.0 & 3430 & 10907 & 13.5 \\
\hline 2008Q3 & -1.9 & 26.2 & -7.5 & 11176 & -11924 & 13.1 \\
\hline 2008Q4 & -1.5 & 26.2 & -5.4 & 45941 & -111675 & 17.2 \\
\hline 2009Q1 & -0.1 & 27.7 & -6.7 & 13642 & 9054 & 20.0 \\
\hline 2009Q2 & -9.6 & 27.7 & -3.5 & 21222 & 29259 & 20.5 \\
\hline
\end{tabular}

Source: South African Reserve Bank, Quarterly Bulletin, various issues 
Some of these variables, like foreign debt, are the same across the two periods and indicate a structural reliance on foreign capital that did not change over the decade. Within these long-term trends, there was also pronounced changes in the foreign debt position during specific crisis months. For example, the rand value of total external debt rose from R190.8 billion at the end of 1997 to R228.9 billion at the end of June 1998 partly due to the sharp depreciation of the rand against the dollar in the first half of 1998. Foreign debt as a percentage of gross domestic product increased only marginally from 30.4\% at the end of 1997 to $30.9 \%$ at the end of June 1998 . Almost the same is true about the current account deficit. South Africans are used to these outflows; however, it has shown a consistent increase as percentage of GDP over the two periods - a potential weakness and cause for concern.

Another striking feature portrayed by Table 3 is the increase in both net direct investment and portfolio investment since 1997. These inflows have helped to balance the increasing outflows due to imports. The volatility and changing nature of portfolio flows in particular is a cause for concern and leaves the country exposed.

In contrast to the fundamental weaknesses in the East Asian countries, South Africa had a fundamentally sound financial system, a flexible exchange rate system and more sustainable budget and balance of payments deficits (South African Reserve Bank, 1998). In both crisis periods, there was a marked change in the level and composition of capital flows compared to more tranquil times. An important remedial policy initiative in this regard was the elimination of the oversold net open position in foreign currency (NOFP) of the South African Reserve Bank (which stood at US\$23.2 billion at the end of September 1998), which was achieved in May 2003. Successful price stabilisation policies in the form of inflation targeting were introduced. The Reserve Bank also adopted a policy of non-intervention in the foreign exchange market.

The budget deficit has improved since the first crisis period. The unusual deficit during 2009 is a symptom of the first South African recession since August 1999. The fundamental economic indicators overall indicate more vulnerability during the East Asian and Russian crisis, and the main reason for this is the country's foreign reserve position.

In contrast, at the onset of the 2007-09 global crisis, the foreign reserve position of South Africa was much healthier. For both 2008 and 2009 as a whole, the country's net international reserves showed a marked increase. International reserves advanced by US $\$ 5.6$ billion from the end of 2008 to the end of 2009. In line with its exchange rate policy of non-intervention, the Bank did not use its reserves to influence the exchange rate of the rand and has not been required to use its reserves in any way to support the stability of the financial system. South Africa was one of a group of emerging market countries that managed the crisis without significant depletion of international reserves (Aizenman \& Pinto, 2011, p. 19).

In terms of public debt management, South Africa did not have the problems that plagued the East Asian countries, such as a high percentage of short-term foreign debt. Nevertheless, the public debt position improved during this time period. By 2008, South Africa was running a small budget surplus in 2008 and the debt/GDP ratio stood at $27 \%$. This compares to a budget deficit of $6.2 \%$ at the start of 1997 , while total foreign debt as percentage of GDP remained relatively stable during the period under investigation.

The South African financial system did not share the same macroeconomic fundamentals as those that are widely described as the causes of the global financial crisis of 2007-09. Most notably, South African banks had no exposure to "sub-prime" assets, and very limited exposure to derivative instruments, asset-backed securities, and foreign assets. Several policy initiatives contributed to the development of the domestic banking market. For example, the National Credit Act (NCA) of 2007 contains provisions to protect consumers from reckless lending practices. Complementary regulatory initiatives in this regard include increased capital adequacy requirements and setting conservative leverage ratios and prudential regulatory limits to foreign exposure. The experience of the small banking crisis in 2002 and the implementation of the Basel II Capital Accord in 2008 have led to improved risk management practices and stronger crisis management arrangements.

Several operational and regulatory changes to the operations of the JSE came into effect in 1995. These regulatory changes included a new JSE constitution and the adoption of improved trading systems. SETS, a London- 
based trading system that allowed automatic execution of trades, information efficiency, and reduced the incidence of insider trading, was introduced in 2002. Gradual liberalisation of exchange controls, which started in 1997, further broadened the investor base and resulted in higher turnover and liquidity on the JSE. For example, liquidity levels increased from 20\% in 1998 to 62\% in 2008 (South African Reserve Bank, various issues).

\section{ECONOMETRIC STUDY: SPILLOVER EFFECTS FROM GLOBAL MARKETS TO THE JSE}

This section of the paper empirically investigates which stock markets had the biggest impact on the JSE during the two crisis periods, particularly in terms of volatility transmission, and ascertains whether or not this impact changed between the two crisis periods.

\subsection{Data}

The stock price data used, measured in US dollars, was obtained from the database Thomson Reuters Datastream. Datastream compiles its own "total market" share price index per individual country. From the raw downloaded daily closing indices, weekly averages were calculated. Rates of return for all the indices were calculated as a percentage log difference. By using weekly data, the problem of missing daily data is partly addressed.

Apart from South Africa, twelve countries are included in the empirical study. Developed markets are represented by the stock market indices of the USA, UK, Germany, and Australia. South Africa is currently classified as an "advanced emerging stock market" by the FTSE; therefore Brazil, Hungary, Mexico, and Taiwan are included to complete the group of "advanced emerging stock markets." Countries from another emerging markets grouping are also included: Brazil, Russia, India, and China together with South Africa are part of the so-called "BRICS" countries. The last country to be included is Thailand. Thailand is also classified as an emerging market and is included because the devaluation of the Thai baht started the 1997-1998 East Asian crisis.

Two eighteen-month periods were identified to represent the two crisis periods: July 1997 - December 1998 and July 2008 - December 2009. The first period includes the start of the East Asian crisis, the aftermath of the East Asian crisis and the Russian crisis of August 1998 (Voronkova, 2004). The second period includes the 15 September 2008 Lehman Brothers collapse and the response of world markets to it. According to Frankel and Saravelos (2010) equity prices suggest that the global financial crisis began in earnest in September 2008 and ended in May 2009. Even though the crisis periods could be narrowed down further to only six months, the empirical technique requires a longer data set.

\subsection{Volatility Transmission (Bi-Variate GARCH)}

In financial markets, periods of uncertainty tend to increase the volatility of asset returns. During crisis periods volatilities also move together across financial assets and different countries. In this regard multivariate GARCH (MGARCH) models help to identify relations between volatilities and co-volatilities of different markets (Bollerslev, 1990). Among the MGARCH models specified as linear combinations of univariate GARCH models are: the diagonal VECH, diagonal BEKK, and constant conditional correlation (CCC) models. Diagonal VECH is the most unrestricted of the three, but it does not guarantee a positive semi-definite conditional covariance matrix. CCC is the most restricted of the three models and reduces the numbers of estimated parameters and simplifies the estimation process (Bauwens, Laurent, \& Romouts, 2006).

The limited number of observations for each crisis period does not allow the estimation of a MGARCH model including all 13 countries in this study. Therefore twelve separate bi-variate GARCH models, CCC specification, were estimated to model the transmission of stock market volatility between South Africa and each of the identified countries. (Diagonal VECH and BEKK specifications did not render positive semi-definite conditional covariance matrices.)

In the two mean equations, each country's weekly stock market return is estimated as a constant. In the covariance specification, three equations are specified: a GARCH(1,1) model for each of the two countries (see 
Equations 1 and 2 below) and a covariance equation (see Equation 3 below) including the square root of the product of the two GARCH terms:

$\mathrm{GARCH} 1=\mathrm{C}(3)+\mathrm{C}(4) * \operatorname{RESID} 1(-1)^{\wedge} 2+\mathrm{C}(5)^{*} \mathrm{GARCH} 1(-1)$

$\mathrm{GARCH} 2=\mathrm{C}(6)+\mathrm{C}(7) * \operatorname{RESID} 2(-1)^{\wedge} 2+\mathrm{C}(8) * \operatorname{GARCH} 2(-1)$

COV1_2 =C (9)*@SQRT(GARCH1*GARCH2)

Table 4 summarises the covariance coefficients (c(9) in Equation 3) between South Africa and all 12 countries across the two crisis periods. These covariance coefficients are interpreted as indicators of volatility transmission. ${ }^{2}$

Table 4: Estimates of Volatility Covariance

\begin{tabular}{|l|c|c|c|c|c|c|}
\hline & \multicolumn{2}{c|}{ East Asian/Russian Crisis } & \multicolumn{3}{c|}{ Global Financial Crisis } \\
\hline \multicolumn{1}{|c|}{ Country } & coefficient & Z-stat & prob & coefficient & Z-stat & prob \\
\hline Australia & 0.4972 & 4.26 & 0.000 & 0.8283 & 25.66 & 0.000 \\
\hline Brazil & 0.5642 & 6.47 & 0.000 & 0.8611 & 19.67 & 0.000 \\
\hline China & 0.1673 & 1.36 & 0.174 & 0.3567 & 2.67 & 0.008 \\
\hline Germany & 0.5545 & 6.23 & 0.000 & 0.8886 & 28.11 & 0.000 \\
\hline Hungary & 0.5472 & 6.19 & 0.000 & 0.8498 & 25.30 & 0.000 \\
\hline India & 0.2899 & 2.65 & 0.008 & 0.6755 & 8.75 & 0.000 \\
\hline Mexico & 0.6493 & 8.94 & 0.000 & 0.8073 & 16.42 & 0.000 \\
\hline Russia & 0.5466 & 4.88 & 0.000 & 0.7506 & 13.92 & 0.000 \\
\hline Taiwan & 0.4530 & 4.37 & 0.000 & 0.6394 & 7.36 & 0.000 \\
\hline Thailand & 0.5691 & 5.51 & 0.000 & 0.6854 & 12.47 & 0.000 \\
\hline UK & 0.5084 & 4.87 & 0.000 & 0.8524 & 23.57 & 0.000 \\
\hline US & 0.5540 & 6.45 & 0.000 & 0.8737 & 27.06 & 0.000 \\
\hline
\end{tabular}

Source: Authors' own estimates using EViews. Each sample period includes 79 observations. Volatility of weekly returns modelled.

Volatility transmission between South Africa and all 12 countries included were higher during the global financial crisis than during the East Asian and Russian crisis - as was expected. The 2008/2009 crisis truly was a global crisis. During both periods, volatility transfer from China was the lowest of all countries. The estimated coefficients for China - which are the only two estimated coefficients that are not statistically significant at a $1 \%$ level - are also the least significant of the 24 that were estimated.

Table 5: Ranking of Volatility Spillover during Both Crisis Periods

\begin{tabular}{|l|c|c|c|c|c|}
\hline \multicolumn{2}{|c|}{ East Asian and Russian Crisis } & \multicolumn{3}{c|}{ Global Financial Crisis } \\
\hline \multicolumn{1}{|c|}{ Country } & Volatility coefficient & Rank & Country & Volatility coefficient & Rank \\
\hline Mexico & 0.6493 & 1 & Germany & 0.8886 & 1 \\
\hline Thailand & 0.5691 & 2 & US & 0.8737 & 2 \\
\hline Brazil & 0.5642 & 3 & Brazil & 0.8611 & 3 \\
\hline Germany & 0.5545 & 4 & UK & 0.8524 & 4 \\
\hline US & 0.5540 & 5 & Hungary & 0.8498 & 5 \\
\hline Hungary & 0.5472 & 6 & Australia & 0.8283 & 6 \\
\hline Russia & 0.5466 & 7 & Mexico & 0.8073 & 7 \\
\hline UK & 0.5084 & 8 & Russia & 0.7506 & 8 \\
\hline Australia & 0.4972 & 9 & Thailand & 0.6854 & 9 \\
\hline Taiwan & 0.4530 & 10 & India & 0.6755 & 10 \\
\hline India & 0.2899 & 11 & Taiwan & 0.6394 & 11 \\
\hline China & 0.1673 & 12 & China & 0.3567 & 12 \\
\hline
\end{tabular}

\footnotetext{
${ }^{2}$ Differences in asset allocation decision of institutional investors could have an impact on the estimated spillover effects. In countries where institutional investors are biased towards equities, the volatility impact would be higher than in markets where portfolios are biased towards bonds. (The authors would like to thank an anonymous reviewer for this comment. However, comparing asset allocation across investors and across countries falls outside the scope of this paper.)
} 
Table 5 ranks the countries in terms of volatility spillover during the two periods. During the East Asian and Russian crisis, the calculated volatility covariance between the South African stock market and the markets of Mexico, Thailand, Brazil, Germany, US, and Hungary were the highest. The impact of Mexico and Thailand can be explained by the East Asian origin of the crisis. Volatility co-movement with Hungary can be explained by the two countries' status as advanced emerging markets. Hungary was one of the Eastern European countries hit hardest by the crisis and required a US $\$ 25.1$ billion credit line from the International Monetary Fund, mainly to improve its public debt position. Hungary had one of the largest budget deficits in the EU.

During the second crisis period, Germany, the US, Brazil, the UK, Hungary, and Australia played the dominant parts. Given that the crisis originated in the US, and given the consequent impact on the real economies of Europe, it is not surprising that the developing countries were the most dominant sources of volatility. Hungary, as an advanced emerging market, features again. The strong impact of Brazil and Australia (in the second crisis) can most likely be attributed to the fact that these stock markets, like South Africa, are dominated by resource (commodity-producing) companies. This provides supporting evidence to the hypothesis that commodity-producing countries were hit particularly hard during the second part of the global financial crisis. Volatility linkages with Germany, particularly in the second crisis period, can be explained by Germany's role as South Africa's main trading partner in Europe. Uncertainty or volatility on the German stock market is likely to enhance uncertainty on the South African market. Volatility co-movement between South Africa and China, and India and Russia respectively is not that high. Despite being part of the BRICS grouping, South Africa is more prone to share periods of high volatility with the developed markets of Germany, US, and UK and fellow advanced emerging markets of Brazil and Hungary.

\section{DISCUSSION AND CONCLUSION}

From the previous section it is evident that both crisis periods considered had a serious impact on the South African stock market and broader economy, despite the fact that the macroeconomic fundamentals in South Africa differed from those in the countries at the centre of the crisis. However, the nature of the impact on the South African economy, and especially on the JSE, differed.

Emerging stock markets were the hardest hit by the East Asian and Russian crisis. For the period July 1997 to October 1998 the developed markets of Germany, UK, and US generated positive returns, while only Australia reported a negative return. All nine emerging markets included in the study reported large negative returns. Hungary, Mexico, and Poland outperformed the South African stock market, while Thailand and the BRIC countries were worse off than South Africa. Since May 1998, during the second part of the crisis, losses on the JSE were more severe - coupled with a strong depreciation of the currency. Overall the JSE was among the worst-performing emerging markets during this period. This crisis was predominantly an emerging markets crisis.

Volatility spillovers from emerging markets to the JSE were more pronounced than those from developed markets. The South African macroeconomic fundamentals were weaker than a decade later - with higher budget deficits and much lower levels of international reserves. The low level of reserves was a crucial weakness amidst a managed floating exchange rate. The South African stock market (and consequently the exchange rate) was more at risk from speculators - and this was reflected in the realised returns.

During the recent global crisis, both developed and emerging markets reported negative returns. However, some emerging markets outperformed the developed markets. For the period September 2007 to September 2008, the South African and Russian stock markets were generally better off than the developed markets. From September 2008 until March 2009 China, Thailand, South Africa, and Brazil outperformed the developed markets included in this study. This was a truly global crisis, with both developed and emerging stock markets adversely affected. However, in contrast to the East Asian and Russian crisis, some emerging markets (including South Africa) were better off than the developed markets. This time the JSE was one of the best-performing emerging markets.

Data on net portfolio investment indicates that South Africa decoupled from developed economies during the sub-prime crisis - with large positive net inflows into the country. The collapse of Lehman Brothers caused massive outflows in the fourth quarter of 2008. During this worst part of the crisis investors withdrew from liquid 
markets like South Africa. These outflows changed into inflows during the first two quarters of 2009. In terms of fundamentals the South African economy was stronger than during the first crisis. The budget deficit was lower and budget surpluses were even recorded. The level of foreign reserves was also much higher - without the burden of a managed floating exchange rate. During this crisis, the JSE experienced more pronounced volatility spillovers from developed markets: the US and UK as two of the most important financial markets, Germany as an important trading partner and other resource-based economies like Brazil and Australia.

\section{AUTHOR INFORMATION}

Anmar Pretorius is a lecturer in Economics on the Potchefstroom campus of the North-West University in Potchefstroom, South Africa. Her research interest includes applied econometrics, financial economics, emerging markets, and local economic development. She has published in these fields in local South African as well as international journals. E-mail: anmar.pretorius@nwu.ac.za (Corresponding author)

Jesse de Beer is a senior lecturer at the Department of Economics, University of the Free State in Bloemfontein, South Africa. Her main research and teaching interest is investments and financial markets, but also behavioural finance, financial regulation, financial literacy, and macroeconomic developments. She obtained her $\mathrm{PhD}$ (Impact of the credit risk proposal of Basel 2 on South African banks) in 2003 from the University of the Free State. She has presented conference papers and published on topics including diversification benefits of emerging markets, the equity risk premium in South Africa, and the impact of financial crises on the JSE. E-mail: debeerja@ufs.ac.za

\section{REFERENCES}

1. Aizenman, J., \& Pinto, B. (2011). Managing financial integration and capital mobility policy lessons from the past two decades. World Bank Policy Research Paper 5786.

2. Aloui, R., Aïssa, M. S. B., \& Nguyen, D. K. (2011). Global financial crisis, extreme interdependences, and contagion effects: The role of economic structure? Journal of Banking \& Finance, 35(1), 130-141.

3. Bank for International Settlements. (2009). 78th Annual Report. Basle, Switzerland.

4. Basu, R. (1998). Contagion crises: The investors' logic, mimeograph. UCLA Los Angeles.

5. Bauwens, L., Laurent, S., \& Romouts, J. V. K. (2006). Multivariate GARCH models: A survey. Journal of Applied Econometrics, 21, 79-109.

6. Bekaert, G., Ehrmann, M., Fratzscher, M., \& Mehl, A. (2011). Global crises and equity market contagion. (NBER Working Paper 17121). Cambridge, Massachusetts, National Bureau of Economic Research.

7. Bollerslev, T. (1990). Modeling the coherence in short-run nominal exchange rates: A multivariate generalized ARCH model. Review of Economics and Statistics, 72, 498-505.

8. Boshoff, W. H. (2006). The transmission of foreign financial crises to South Africa: A firm-level study. Journal for Studies in Economics and Econometrics, 30(2), 61-85.

9. Bruinshoofd, A., Candelon, B., \& Raabe, K. (2010). Banking sector strength and the transmission of currency crises. Open Economies Review, 21(2), 263-292.

10. Brunnermeier, M., \& Pedersen, L. (2009). Market liquidity and funding liquidity. Review of Financial Studies, 22, 2201-2238.

11. Caballero, R. J., Farhi, E., \& Gourinchas, P. (2008). Financial crash, commodity prices, and global imbalances. Brookings Papers on Economic Activity, Fall, 1-55.

12. Calvo, G., \& Mendoza, E. (1998). Rational herd behavior and the globalization of securities market. Mimeo, University of Maryland.

13. Caramazza, F., Ricci, L. A., \& Salgado, R. (2000). Trade and financial contagion in currency crisis. (IMF Working Paper no. 55). International Monetary Fund.

14. Chen, N., Roll, R., \& Ross, S. (1986). Economic forces and the stock market. Journal of Business, 59(3), 383-403.

15. Chinzara, Z. (2011). Macroeconomic uncertainty and conditional stock market volatility in South Africa. South African Journal of Economics, 79, 27-49.

16. Chinzara, Z., \& Aziakpono, M. (2009). Dynamic returns linkages and volatility transmission between South African and the world major stock markets. Journal of Studies in Economics and Econometrics, 33(3), 69-94. 
17. Chudik, A., \& Fratzscher, M. (2011). Identifying the global transmission of the 2007-09 financial crisis in a GVAR model. (ECB working paper no 1285).

18. Claessens, S., \& Forbes, K. (2004). International financial contagion: The theory, evidence and policy implications. The IMF's Role in Emerging Market Economies: Reassessing the Adequacy of its Resources. RBWC, DNB and WEF, Amsterdam, November 18-19.

19. Claessens, S., Kose, A. M., \& Terrones, M. E. (2009). What happens during recessions, crunches, and busts? Economic Policy, 24(60), 653-700.

20. Coetzee, C. (2002). Monetary conditions and stock returns: A South African case study. Finance 0205002 , EconWPA.

21. Collins, D., \& Biekpe, N. (2003). Contagion: A fear for African equity markets? Journal of Economics and Business, 55, 285-297.

22. Davis, E. P. (2008). Liquidity, financial crises and the lender of last resort - How much of a departure is the sub-prime crisis? In P. Bloxham \& C. Kent (Eds.), Lessons from the financial turmoil of 2007 and 2008

Reserve Bank of Australia Conference. H. C. Coombs Centre for Financial Studies, 14-15 July, 2008.

23. De Gregorio, J., Edwards, S., \& Valdes, R. O. (2000). Controls on capital inflows: do they work? Journal of Development Economics, 63(1), 59-83.

24. Didier, T., Love, I., \& Peria, M. S. M. (2010). What explains stock markets' vulnerability to the 2007-2008 crisis? (World Bank Policy Research Working Paper No. 5224).

25. Dungey, M., Fry, R., González-Hermosillo, B., Martin, V. L., \& Tang, C. (2010). Are financial crises alike? (IMF Working paper no. 14). International Monetary Fund.

26. Durodola, D. O. (2006). An empirical investigation of the determinants of stock market behaviour in South Africa. (Master's Thesis). Rhodes University.

27. Ehrmann, M., Fratzscher, M., \& Mehl, A. (2009). What has made the current financial crisis truly global? (Unpublished ECB Working Paper). May 2009.

28. Eichengreen, B., \& Rose, A. (1998). Staying afloat when the wind shifts: External factors and emergingmarket banking crises. (NBER Working Paper No. 6370). Cambridge, Massachusetts, National Bureau of Economic Research.

29. Eichengreen, B., Rose, A., \& Wyploz, C. (1996). Speculative attacks on pegged exchange rates: An empirical exploration with special reference to the European Monetary System. (NBER Working Paper no. 4898). Cambridge, Massachusetts, National Bureau of Economic Research.

30. Eichengreen, B., \& Wyplosz, C. (1993). The unstable EMS. Brookings Papers on Economic Activity, 1, 51124.

31. Forbes, K., \& Rigobon, R. (2002). No contagion, only interdependence: measuring stock market comovements. Journal of Finance, 57(5), 2223-2261.

32. Frankel, J., \& Saravelos, G. (2010). Are leading indicators of financial crisis useful for assessing country vulnerability? Evidence from the 2008-2009 global crises. (NBER Working Paper no. 16047). Cambridge, Massachusetts, National Bureau of Economic Research.

33. Fratzscher, M. (2000). On currency crises and contagion. (Institute for International Economics Working Paper no 9).

34. Froot, K. A., O'Connell, P. G. J., \& Seasholes, M. S. (2001). The portfolio flows of international investors. Journal of Financial Economics, 59, 151-193.

35. Glick, R., \& Rose, A. K. (1999). Contagion and trade: Why are currency crises regional? Journal of International Money and Finance, 18, 603-617.

36. Goldstein, M. (1998). The Asian financial crisis: Causes, cures, and systemic implication. Policy Analyses in International Economics, 55. Washington, DC: Institute for International Economics.

37. Gordon, M. J. (1962). The Investment, financing, and valuation of the corporation. Homewood: Irwin Publishers.

38. Gros, D., \& Micossi, S. (2008). Crisis management tools for the Euro area. In A. Felton \& C. M. Reinhart (eds.), The first global financial crisis of the 21st century part II June-December 2008. Retrived 30 September 2008 from VoxEU.org

39. Hernándes, L. F., \& Valdés, R. O. (2001). What drives contagion: trade, neighborhood, or financial links? (IMF Working Paper no. 29). International Monetary Fund.

40. International Monetary Fund. (1998). Financial crises: Causes and indicators in World Economic Outlook. World Economic and Financial Surveys, Washington, May. 
41. International Monetary Fund. (2000). Asset prices and the business cycle in World Economic Outlook. World Economic and Financial Surveys, Washington, May.

42. International Monetary Fund. (2008). Spillovers to emerging equity markets in Global Financial Stability Report. World Economic and Financial Surveys, Washington, October.

43. International Monetary Fund. (2010). How did emerging markets cope in the crisis? International Monetary Fund Policy Paper. Washington DC. Retrieved from http://www.imf.org/external/np/pp/eng/ 2010/061510.pdf

44. Kaminsky, G. L. (1999). Currency and banking crises - The early warnings of distress. (IMF Working Papers 99). International Monetary Fund.

45. Kaminsky, G. L., Lizondo, S., \& Reinhart, C. M. (1998). Leading indicators of currency crises. Staff Papers - International Monetary Fund, 45(1), 1-48.

46. Kaminsky, G. L., \& Reinhart, C. M. (2003). The center and the periphery: The globalization of financial turmoil. (NBER Working Paper no 9479.) Cambridge, Massachusetts, National Bureau of Economic Research.

47. Kaminsky, G. L., \& Schmukler, S. L. (1999). What triggers market jitters? A chronicle of the Asian Crisis. (Policy Research Working Paper WPS2094) The World Bank.

48. Kaminsky, G. L., Lyons, R., \& Schmukler, S. (2001). Mutual fund investment in emerging markets: An overview. In S. Claessens \& K. Forbes (Eds.), International financial contagion (pp. 158-85). Boston: Kluwer Academic Publishers.

49. Kodres, L., \& Pritsker, M. (2002). A rational expectations model of financial contagion. Journal of Finance, 57, 769-800.

50. Krugman, P. (1979). A model of balance-of-payments crises. Journal of Money, Credit, and Banking, 11(3), 311-325.

51. Kumar, M. S., \& Persaud, A. (2001). Pure contagion and investors' shifting risk appetite: Analytical issues and empirical issues. (IMF Working Paper 134). International Monetary Fund.

52. Masson, P. (1998). Contagion: Monsoonal effects, spillovers, and jumps between multiple equilibria. (IMF Working Paper 98) International Monetary Fund.

53. Moolman, E., \& Du Toit, C. (2005). An econometric model of the South African stock market. South African Journal of Economics, 8(1), 77-91.

54. Moosa, I. (2010). Stock market contagion in the early stages of the global financial crisis: The experience of the GCC countries. International Journal of Banking and Finance, 7(1), 19-34.

55. Obstfeld, M. (1996). Models of currency crises with self-fulfilling features. European Economic Review, 40, 1037-1047.

56. Rose, A., \& Spiegel, M. (2009). Cross-country causes and consequences of the 2008 crisis: Early warning. Japan and the World Economy, 24(1), 1-16.

57. Samouilhan, N. L. (2006). The relationship between international equity market behaviour and the JSE. South African Journal of Economics, 74(2), 249-260.

58. Shiller, R. J. (2000). Irrational Exuberance. Princeton, Princeton University Press.

59. South African Reserve Bank. Quarterly Bulletin, various issues.

60. Van Rijckeghem, C., \& Weder, B. (2001). Sources of contagion: Is it finance or trade? Journal of International Economics, 54, 293-308.

61. Voronkova, S. (2004). Equity market integration in Central European emerging markets: A cointegration analysis with shifting regimes. International Review of Financial Analysis, 13, 633-647.

62. World Economic Forum. (2010). Global Competitiveness Report 2010. Geneva, World Economic Forum. 


\section{NOTES}

